Spectacular Passions 



\section{Spectacular Passions}

CINEMA, FANTASY, GAY MALE SPECTATORSHIPS

BRETT FARMER

Фuke Eniversity Press durham and london 2000 
(ㄱ) 200o Duke University Press

All rights reserved

Printed in the United States of

America on acid-free paper $@$

Typeset in Janson by Tseng

Information Systems, Inc.

Library of Congress Cataloging-in-

Publication Data appear on the last printed page of this book. 
For Peter 
